\title{
PENGGETASAN LOGAM CAIR PADA CAPILLARY TUBE BAJA TAHAN KARAT 316
}

\author{
LIQUID METAL EMBRITTLEMENT (LME) OF 316 \\ STAINLESS STEEL CAPILLARY TUBE
}

\author{
Apriardi Ihlas \\ Balai Besar Bahan dan Barang Teknik, Jl. Sangkuriang No. 14 Bandung 40135 \\ Email: apriardi.ihlas@gmail.com
}

Diterima: 23 April 2015

Direvisi: 20 Mei 2015

Disetujui: 18 Juni 2015

\begin{abstract}
ABSTRAK
Capillary tube adalah komponen yang berfungsi mengalirkan larutan kimia (scale inhibitor) ke dalam sumur minyak yang berpotensi membentuk kerak. Telah terjadi penyumbatan (clogging) dan retak-retak pada komponen capillary tube yang berbahan baja tahan karat austenit 316. Pemasangan komponen tersebut berada dalam satu kesatuan unit dengan komponen lain yang bernama centriline cel flat. Untuk mengetahui lebih lanjut penyebab terjadinya kerusakan, dilakukan serangkaian pemeriksaan dan pengujian. Pemeriksaan tersebut meliputi: data awal dan kronologi, visual, metalografi (makro dan mikro), dan Scanning Electron Microscopy/ Energy Dispersive X-ray Spectroscopy (SEM-EDS). Hasil pemeriksaan menunjukkan adanya penetrasi seng pada permukaan tube. Penetrasi seng yang mencair mencapai batas butir akan membentuk senyawa intermetallic seng-nikel yang akan mengakibatkan terjadinya perubahan fasa austenit menjadi ferit. Perubahan internal stress akibat perubahan volum fasa inilah yang menyebabkan terjadinya retakan di batas butir.
\end{abstract}

Kata kunci: penggetasan logam cair, baja tahan karat austenit, baja galvanis, retakan batas butir

\section{ABSTRACT}

A capillary tube is a component that serves the chemical solution (scale inhibitor) into the oil wells, which could potentially form the crust. There have been obstructions (clogging) and cracks in the capillary tube components made from austenitic stainless steel 316. The installation of these components is in one unit with another component called "centriline cel flat". To know more about the cause of the occurrence of the damage, a series of inspection and testing was carried out.The inspection included: initial data and chronology, visual, metallography (macro and micro), and Scanning Electron Microscopy/ Energy Dispersive X-ray Spectroscopy (SEM-EDS). The result of the inspection suggested that a penetration of zinc on the surface of the tube existed. The penetration of zinc melting up to the grain limit will form zinc-nickel intermetallic compounds that will result in a change of austenite into a ferrite phase. The internal stress changes due to changes in the phase volume is the cause of the occurrence of cracks at grain boundary.

Keywords: liquid metal embrittlement, austenitic stainless steel, galvanized steel, intergranular cracking

\section{PENDAHULUAN}

Capillary tube adalah komponen yang berfungsi mengalirkan larutan kimia ke dalam sumur minyak yang berpotensi membentuk kerak [1]. Komposisi utama larutan kimia tersebut adalah Phosphate $\left(\mathrm{PO}_{4}\right)$, Chromium $(\mathrm{Cr})$, dan Silica. Adanya larutan kimia ini memperlambat terbentuknya kerak. Material tube tersebut adalah baja tahan karat austenit 316, dengan beberapa alasan pemilihan bahan tersebut. Secara umum, baja tahan karat ini relatif baik ketahanan korosinya, terutama korosi sumuran akibat lingkungan air laut (offshore) yang mengandung klor. Selain itu kemudahan fabrikasi, harga, pengelasan, tingkat kebersihan dan sifat fleksibilitasnya juga menjadi pertimbangan dalam pemilihan. Oleh karena itu, bahan ini dipilih untuk mengalirkan larutan kimia inhibitor terhadap terbentuknya kerak dalam sumur minyak. 
Pemasangan capillary tube berada dalam satu kesatuan unit yang bernama centriline cel flat yang terdiri dari: conductor, insulation, lead sheet, bedding tape, inner ammor, tube, dan outer ammor yang mempunyai fungsi masing-masing (lihat di data teknis). Susunan ini tergantung dari fabrikator pembuatannya. Pada analisa kerusakan ini akan dilihat akibat dari susunan tersebut.

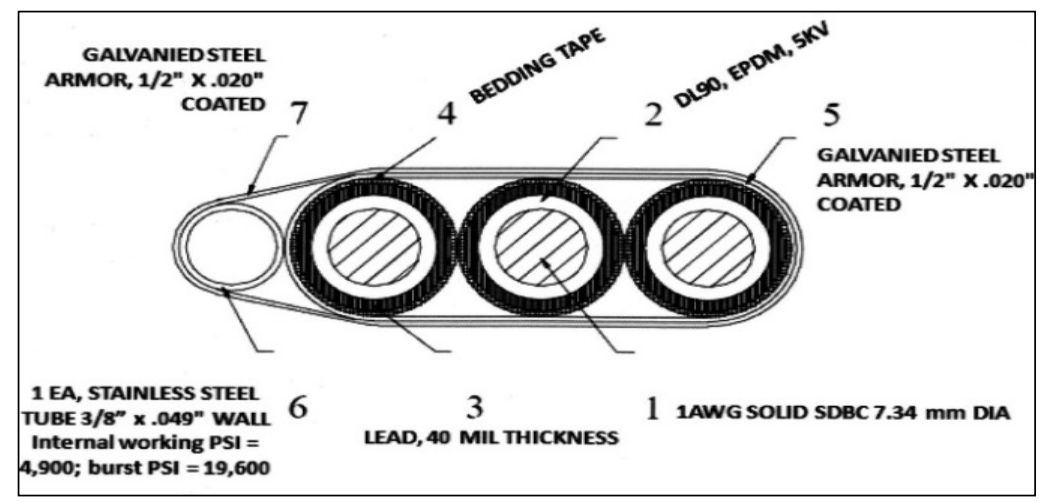

Gambar 1. Skema Susunan Komponen pada Capillary String yang Rusak

Peristiwa penyumbatan (clogging) dan retak-retak telah terjadi pada tube tersebut. Tube yang retak diduga karena pengaruh lingkungan disekitarnya, yaitu korosi. Ada dua jenis korosi yang umumnya menyerang baja tahan karat austenit (dan daerah las), yaitu SCC (Stress Corrosion Cracking) dan IGC (Intergranular Corrosion) [2]. Selain itu ada jenis fenomena korosi lain meskipun jarang terjadi, yaitu Liquid Metal Embrittlement (LME). Namun tidak mudah membedakan kedua tipe kerusakan yaitu IGC dan LME karena kedua jenis korosi tersebut terjadi di batas butir.

Berdasarkan skema susunan komponen di atas, telah terjadi kontak antara capillary string yang terbuat dari galvanized steel terhadap capillary tube 316 (no 6). Kondisi ini mengindikasikan terjadinya fenomena pengge-tasan logam cair seng terhadap baja tahan karat 316.

Penggetasan akibat logam cair atau terkenal dengan istilah Liquid Metal Embrittlement (LME) adalah suatu bentuk retak yang terjadi akibat logam cair yang bersentuhan dengan paduan tertentu. Retakan dapat terjadi secara tiba-tiba dan bersifat getas $[2,3,4,5,6]$.

Mekanisme terjadinya kerusakan capillary tube 316 diamati melalui pemeriksaan dan pengujian di laboratorium. Jadi tujuan dari penelitian ini adalah membuktikan bahwa penggetasan logam cair seng menjadi penyebab retakan pada tube tersebut. Selain itu, dapat menjelaskan tahapan kerusakannya.

\section{BAHAN DAN METODE}

Penelitian ini dimulai dari informasi kronologi kejadian dan data teknis yang dimiliki. Ada 2 komponen capillary tube yang akan diperiksa, yaitu yang rusak (kode A) dan yang tidak rusak (kode B). Komponen tersebut berada dalam rangkaian unit yang dinamakan centriline cel flat. Akan ditentukan rangkaian pemeriksaan dan tentu juga lokasi pengujian terhadap kedua capillary tube.

Rangkaian pemeriksaan atau pengujian tersebut terdiri dari [2]:

1. Pemeriksaan visual untuk memberi gambaran umum penyebab kerusakan.

2. Pengujian komposisi kimia sebagai verifikasi material capillary tube. Pemeriksaan komposisi kimia menggunakan metode spektro emisi [7].

3. Pemeriksaan struktur makro untuk melihat posisi sambungan las. Pengujian ini mengikuti standar ASTM E 340-15 [8].

4. Pemeriksaan struktur mikro/metalografi untuk melihat struktur mikro dan model retakan. Pengujian ini mengikuti standar ASTM E 407-07 (2015) [9].

5. Terakhir pemeriksaan SEM/EDS untuk mengetahui morfologi mikro permukaan patah dan memastikan keberadaan penetrasi seng.

\section{Data Teknis}

Data teknis dan kondisi operasi komponen capillary tube yang rusak di bawah ini. 
Komoditi : Stainless steel tube 316 SS $3 / 8 ” x$ 0.049” wall with internal working 4,900 psi and burst 19,600 psi

Larutan kimia : Phosphate $\left(\mathrm{PO}_{4}\right)$, Chromium (Cr), dan Silica

Kedalaman : 3000 kaki

\section{HASIL DAN PEMBAHASAN}

\section{Pemeriksaan Visual}

Pemeriksaan visual dilakukan untuk mengetahui indikasi awal arah analisa kerusakan untuk mendapatkan akar masalahnya. Ada 2 komponen capillary tube yang akan diperiksa, yaitu yang rusak (kode A) dan yang tidak rusak (kode B). Secara umum, komponen unit centriline cel flat dan bagiannya ditunjukkan pada Gambar 2.

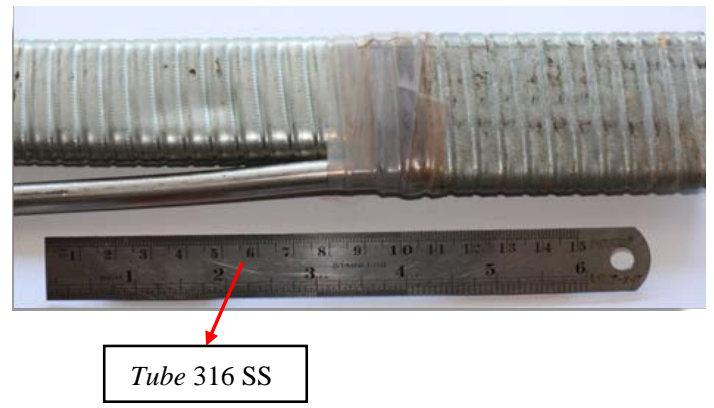

Gambar 2. Tube 316 SS pada Unit Centriline Cel Flat

Pada semua tube yang rusak memperlihatkan bekas jejak radial yang seragam yang diduga berasal dari cengkeraman pelindung terluar, yaitu capillary string yang terbuat dari galvanized steel (Gambar 3 dan 4). Capillary string memiliki profil yang khas sehingga hanya terjadi kontak pada bagian yang menonjol ke dalam. Hal ini menunjukkan adanya kontak langsung antara galvanized steel yang relatif agak menekan tube 316 SS.

Pengamatan visual lebih jauh terhadap tube yang rusak menunjukkan adanya kecenderungan retak terjadi di lokasi jejak/kontak tersebut (yang selanjutnya disebut retak tranversal) terlihat jelas pada Gambar 3. Selain itu, ditemukan juga retak lurus arah longitudinal tube yang diduga merupakan sambungan las dan akan dibuktikan pada pemeriksaan makro.
Adapun susunan centriline cel flat set yang rusak dan centriline cel flat set yang tidak rusak dapat dibedakan seperti terlihat Gambar 5. Berdasarkan Gambar tersebut terlihat bahwa tube 316 SS tidak rusak karena ada lapisan pelindung sehingga tidak terjadi kontak langsung dengan pelapis

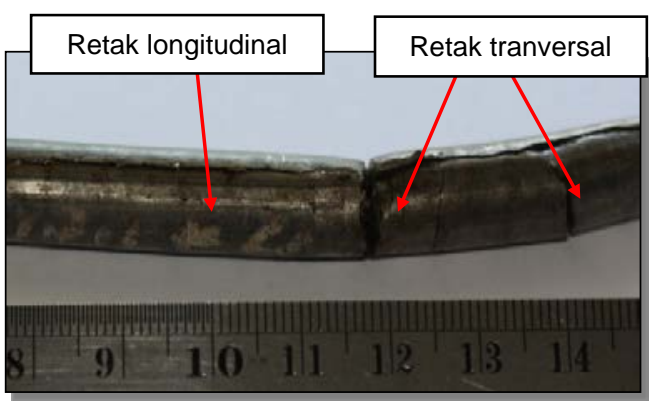

Gambar 3. Lokasi Retakan yang Terjadi pada Tube 316 SS yang Rusak

galvanized steel. Sebaliknya, susunan capillary string set yang rusak karena tidak dilapisi sehingga ada kontak langsung dengan galvanized steel. Berdasarkan pengamatan visual, diduga lapisan pelindungnya sama dengan ketiga kawat tembaga pada Gambar 5, yaitu timbal.

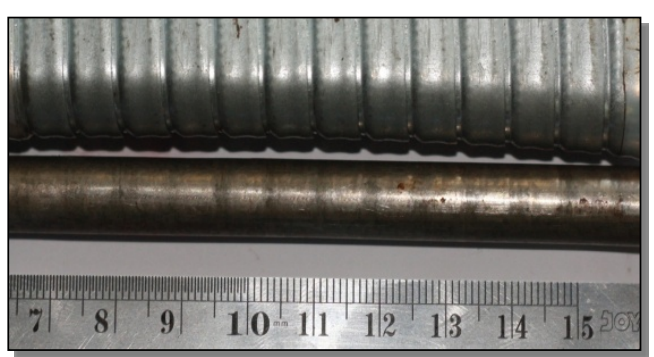

Gambar 4. Bekas Jejak Tube 316 dan Profil Capillary String

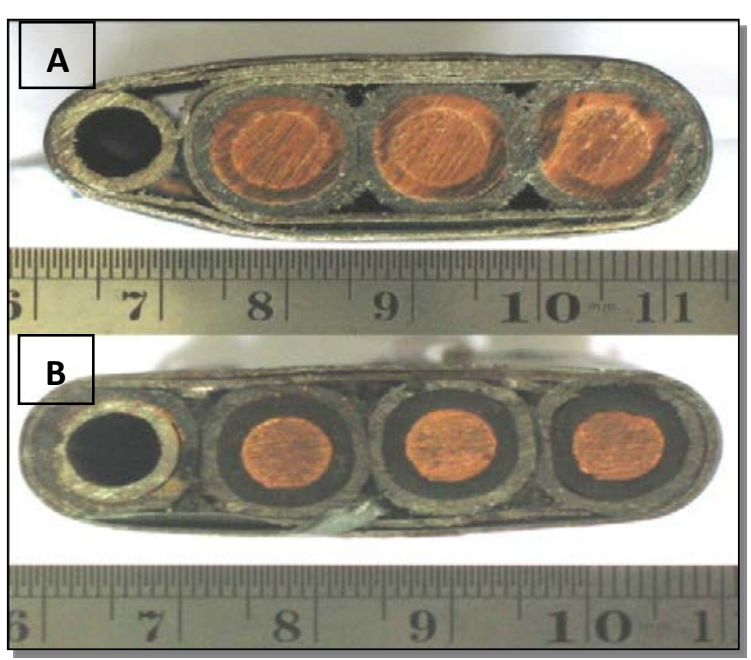

Gambar 5. Susunan Centriline Cel flat yang rusak (A) dan tidak rusak (B) 


\section{Pengujian Komposisi Kimia}

Pengujian komposisi kimia dilakukan sebagai verifikasi material terhadap tube 316 SS pada centriline cel flat set A, B, dan C (tube masih baru) dengan spektro emisi.

Hasil pengujian komposisi kimia pada ketiga tube 316 SS (A, B, dan C) dapat dilihat pada Tabel 1.

Tabel 1. Komposisi Kimia Capillary Tube 316

\begin{tabular}{lccc}
\hline Unsur, \% berat & Tube & Tube & Tube \\
& A & B & C \\
\hline Karbon (C) & 0,0442 & 0,0170 & 0,0152 \\
Silikon (Si) & 0,418 & 0,465 & 0,447 \\
Mangan (Mn) & 1,38 & 1,27 & 1,29 \\
Fosfor (P) & 0,0351 & 0,0321 & 0,0323 \\
Sulfur (S) & 0,0059 & 0,0057 & 0,0058 \\
Krom (Cr) & 16,98 & 16,34 & 16,26 \\
Nikel (Ni) & 10,10 & 10,15 & 10,09 \\
Molibdenum (Mo) & 2,32 & 2,13 & 2,14 \\
Vanadium (V) & 0,121 & 0,104 & 0,0826 \\
Tembaga (Cu) & 0,379 & 0,339 & 0,417 \\
Wolfram (W) & 0,113 & 0,226 & 0,185 \\
\hline
\end{tabular}

Hasil pengujian komposisi kimia pada ketiga tube sesuai dengan ASTM A 312/ A 312M [10].

\section{Pengujian Struktur Makro}

Pengujian struktur makro dilakukan pada penampang melintang tube 316 SS pada centriline celflat set A dan B. Pengujian ini ditujukan untuk melihat ada tidaknya sambungan las. Hasil pengujian dapat dilihat pada Gambar 6 untuk tube $\mathrm{B}$, sedangkan tube A dilanjutkan dengan pemeriksaan struktur mikro/ metalografi.

Berdasarkan pemeriksaan makro terlihat bahwa pada kedua tube terdapat sambungan las dengan arah longitudinal. Berdasarkan arah pengelasan dan bentuk sambungan las, teknologi pengelasan yang diduga adalah sama. Teknologi pengelasan yang umum dilakukan untuk tube tersebut adalah electric resistance welded pipe (ERW), high frequency resistance welding (HFR pipe) [11].

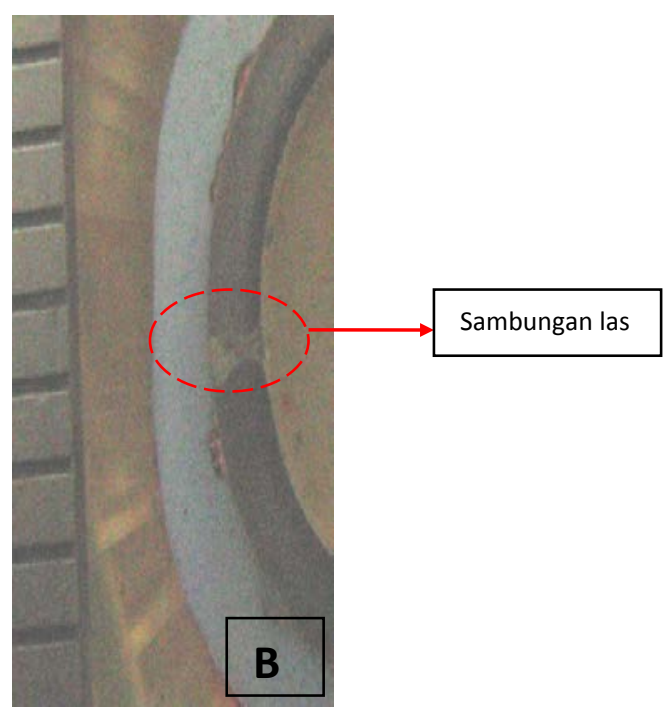

Gambar 6. Foto Makro Sambungan Las pada Tube 316 SS

\section{Pemeriksaan Metalografi}

Pemeriksaan metalografi atau struktur mikro dilakukan lebih fokus pada daerah retak, baik retak transversal maupun retak longitudinal. Preparasi berdasarkan lokasi pengambilan sampel untuk diteruskan dengan mounting, poles, dan proses etsa. Larutan etsa yang dipilih adalah Marble,s (9,12). Secara umum lokasi yang diambil adalah arah melintang terhadap lokasi retakan.

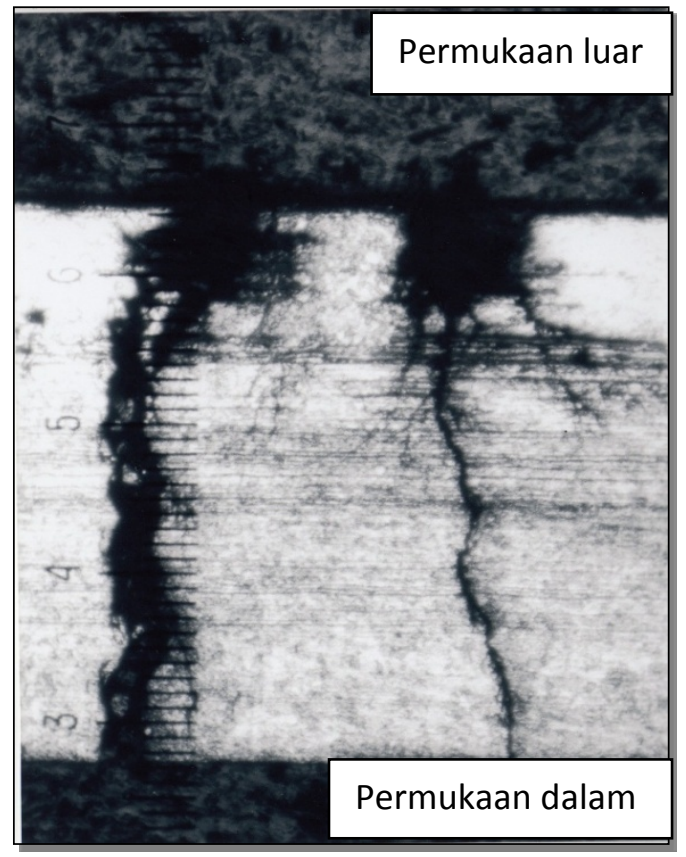

Gambar 7. Struktur Mikro pada Retak Transversal 
Foto pada pemeriksaan retakan tranversal menunjukkan fenomena unik. Struktur mikro pada retak transversal menunjukkan bahwa retakan selalu dimulai dengan adanya kerusakan lokal separuh bola yang cukup dalam sebelum retakan menjalar. Struktur sumuran lokal pada permukaan luar diduga karena adanya kontak langsung dengan seng. Selanjutnya, terjadi retak yang menjalar dan cenderung tegak lurus menuju pusat diameter tube diperlihatkan pada Gambar 7. Retak yang menjalar tersebut cenderung tidak bercabang

Sedangkan struktur mikro pada retak longitudinal terlihat sangat jelas menyerang di daerah logam las. Khusus sisi luar cenderung tepat di tengah atau bondline. Keberadaan bondline ini juga mempertegas bahwa proses pengelasan pada tube adalah ERW.

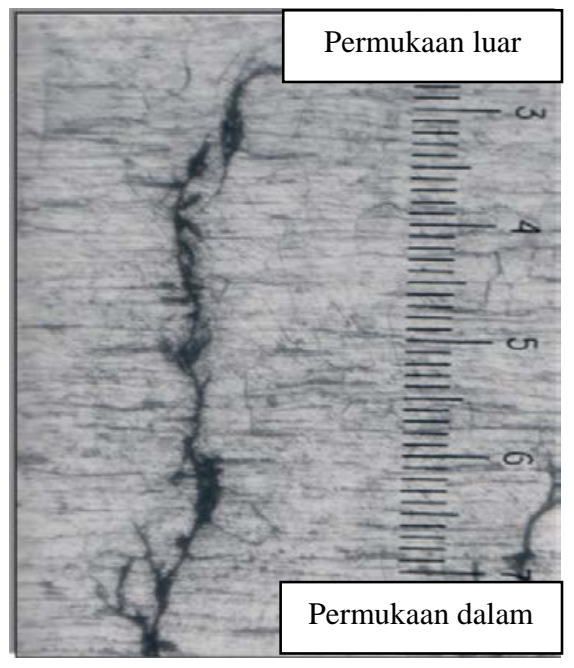

Gambar 8. Retak Intergranular

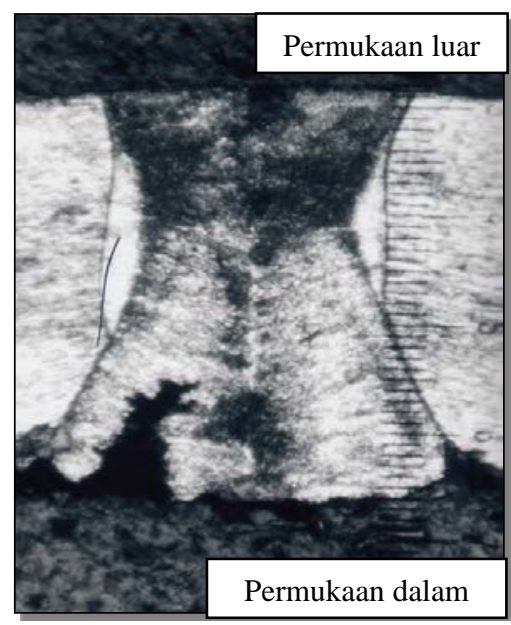

Gambar 9. Struktur Mikro pada Retak Longitudinal
Pada kasus retak longitudinal ini menggunakan sampel yang tingkat kerusakan retaknya belum tembus. Gambar 9 menunjukkan bahwa penyerangan awal korosi tidak hanya dari bagian luar tapi juga dari bagian dalam juga, namun lebih didominasi dari bagian luar. Hal ini diduga ada kaitan yang erat pada perbedaan kemulusan atau reinforcement sambungan las antara bagian luar dan dalam. Bagian luar relatif mulus (tanpa reinforcement), sedangkan bagian dalam disertai reinforcement yang mengakibakan adanya takikan di fusion line dan permukaan las relatif tidak mulus.

Selain itu, tidak adanya korosi yang menyerang sambungan las tube $\mathrm{B}$ (tube yang tidak rusak) dari arah dalam menunjukkan bahwa penyebab retak longitudinal bukan berasal dari larutan kimia (scale inhibitor).

Ada dua jenis korosi yang umumnya menyerang daerah las baja tahan karat austenit, yaitu SCC (Stress Corrosion Cracking) dan IGC (Intergranular Corrosion). Namun dengan ciriciri di atas tidak ada yang sesuai dengan keduanya, yaitu cenderung bercabang untuk SSC dan perambatan merata untuk IGC.Terlebih lagi tidak diawali terjadinya korosi sumuran seperti pada kasus ini.

\section{Pemeriksaan SEM dan EDS}

Pemeriksaan SEM (Scanning Electron Microscope) ditujukan untuk melihat permukaan patahan pada retak dan struktur mikro pada pembesaran tinggi. Sedangkan pemeriksaan EDS dilakukan untuk mengetahui dugaan sejauh mana penetrasi seng pada permukaan retak, selain deposit. Semua pemeriksaan SEM/EDS dilakukan pada ujung retakan, baik retakan transversal maupun retakan longitudinal.

Hasil pemeriksaan SEM menunjukkan bahwa permukaan patahan pada ujung retak tertutupi oleh deposit. Akibatnya, tidak terlihat morfologi permukaan patahan intergranular seperti yang ditunjukkan pada pemeriksaan metalografi. Pada beberapa kasus penggetasan tidak hanya didominasi oleh retakan intergranular, namun juga transgranular [13]. Retakan yang terjadi sangat tergantung pada pasangan material logamnya, karena patah getas dapat terjadi pada kedua tipe retakan tersebut [2].

Pemeriksaan EDS (Energy Dispersive Spectrometry) berupa kurva intensitas terhadap tingkat energi unsur yang ada pada daerah yang dituju dengan kedalaman hanya sampai $2 \mu \mathrm{m}$ dari permukaan [7]. Hasil pemeriksaan EDS terhadap 
kedua jenis ujung retakan menunjukkan kandungan unsur dan komposisi yang relatif sama, dan didominasi oleh senyawa organik dan deposit oksida (berasal dari fluida sumuran), yang terdiri dari tiga jenis kandungan logam yaitu, Besi (Fe), Nikel (Ni), dan Seng (Zn). Sedangkan krom (krom oksida) sebagai pelindung baja tahan karat austenit tidak ditemukan. Hal ini menunjukkan bahwa di luar unsur pemadu tube 316 SS, hanya seng yang ditemukan pada ujung retakan.

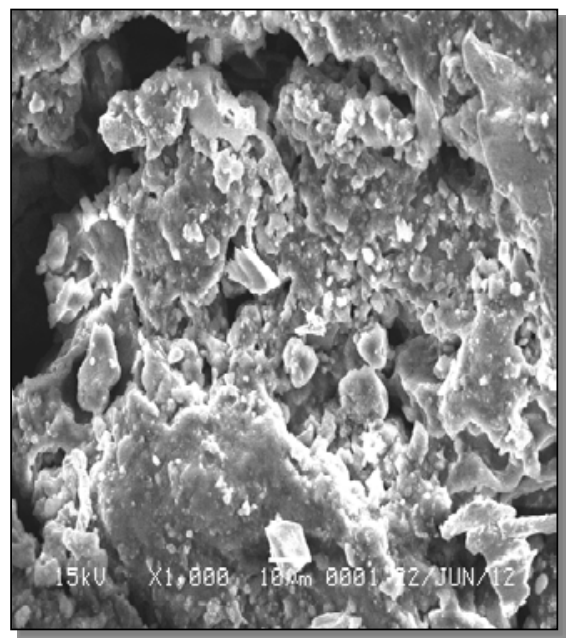

Gambar 10 . Foto SEM pada Ujung Retak Tranversal

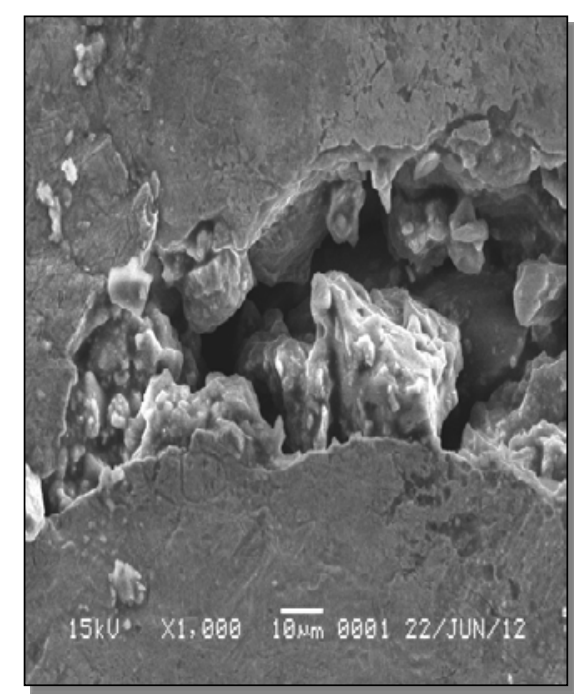

Gambar 11 . Foto SEM pada Ujung Retak Longitudinal

Kandungan seng telah mencapai permukaan ujung retakan longitudinal bagian dalam tube. Hal ini hanya mungkin terjadi setelah kebocoron oleh fenomena LME (Liquid Metal Embrittlement) oleh seng pada retak tranversal dari arah luar. Selain itu fenomena ini menunjukkan juga bahwa seng diffusion tidak hanya berwujud liquid (di atas $750^{\circ} \mathrm{C}$ ) namun juga mencapai temperatur lebih dari $900^{\circ} \mathrm{C}$ (berwujud uap) [14].

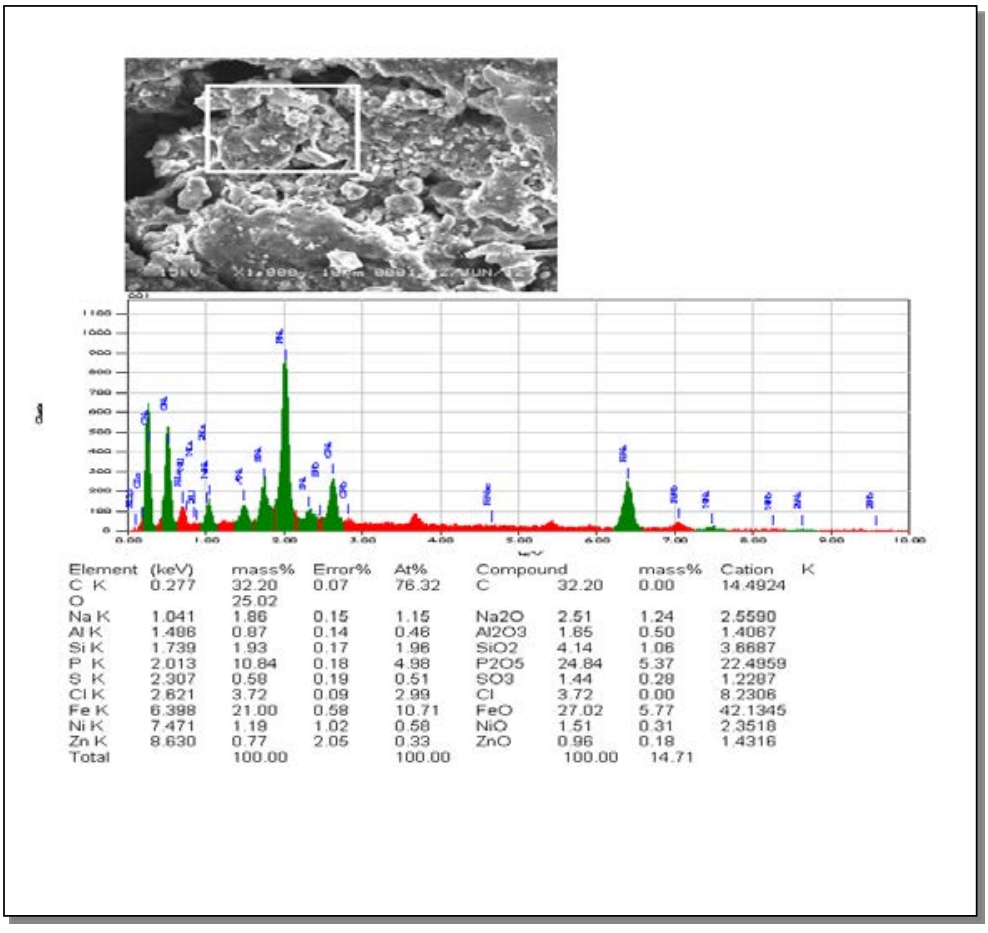

Gambar12. Hasil Pengujian SEM/EDS pada Retak Transversal 


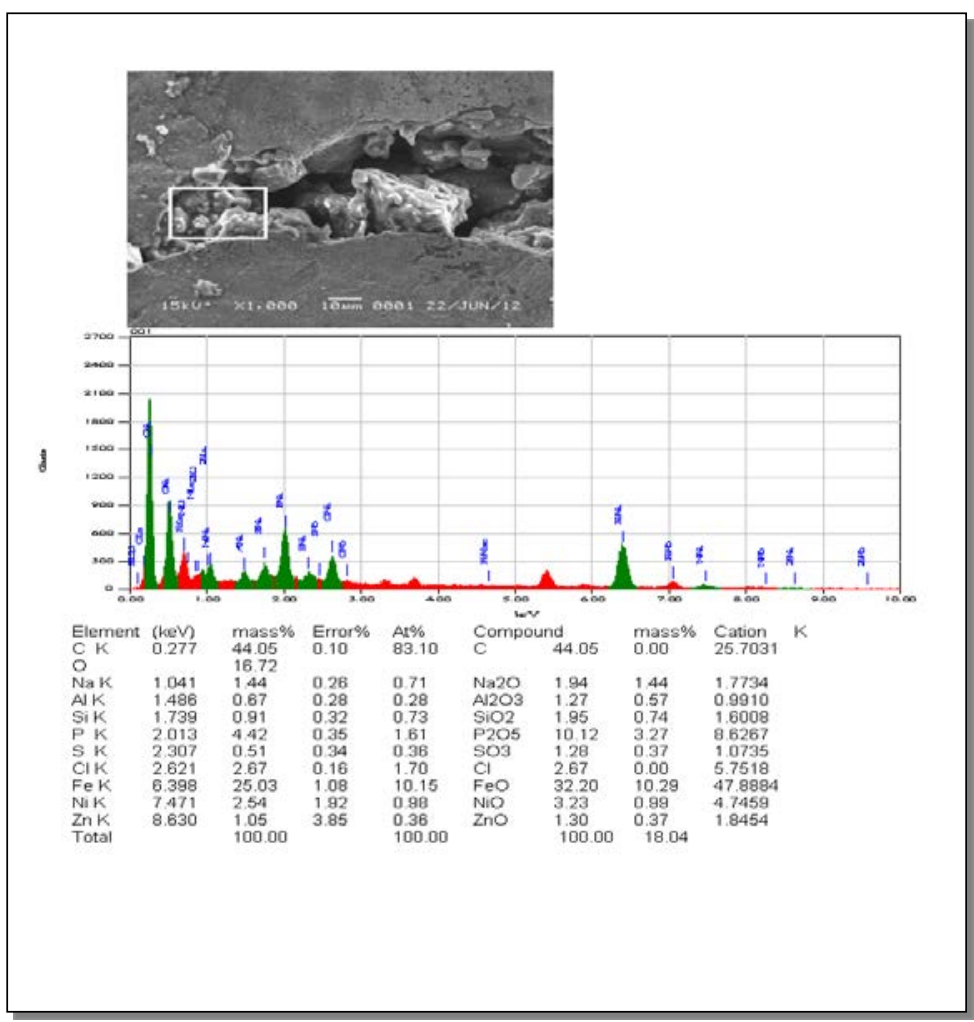

Gambar 13. Hasil Pengujian SEM/ EDS pada Retak Longitudinal

\section{Pembahasan}

Secara umum ada 2 petunjuk utama yang bisa menjelaskan kerusakan pada tube, yaitu pertama adanya penetrasi seng sampai ke ujung retakan. Kedua, terjadinya retakan antar butir dan cenderung tidak bercabang.

Berdasarkan hasil EDS pada kedua ujung retak baik transversal maupun longitudinal melihatkan adanya indikasi yang sama yaitu di temukan unsur seng (lihat pemeriksaan EDS). Hal ini menunjukkan bahwa bagian dalam area las yang tidak mulus/takikan mempermudah terjadinya inisiasi retak akibat penetrasi seng. Jadi, diduga retak yang terjadi mulai dari retak transversal sampai bocor sebelum terjadinya retak longitudinal, kondisi retak transversal jauh lebih parah dibandingkan retak longitudinal.

Skema pada Gambar 14 menunjukkan bahwa pergerakan retak adalah intergranular. Model retakan ini menyerupai retak SCC (Stress Crack Corrosion), namun hanya sedikit bercabang.

Terdapat dua tipe interaksi antara seng dan baja tahan karat austenit seperti yang ditunjukkan pada Gambar 14, yaitu [6] :
1. Tipe I: Proses embrittlement terjadi relatif lambat. Reaksi mulai terjadi pada temperatur $420^{\circ} \mathrm{C}$, ketika seng berwujud cair dan menyebar. Dan ketika mencapai temperatur di atas $750^{\circ} \mathrm{C}$ terjadi reaksi antara seng dan nikel. Difusi nikel ke daerah yang dominan seng untuk membentuk senyawa intermetalik menyebabkan terjadinya kekosongan nikel di dekat batas butir austenit, nickel depletion. Penurunan kandungan nikel menyebabkan terjadinya transformasi fasa dari austenit menjadi ferit. Perbedaan volum antara kedua fasa tersebut akan mengakibatkan munculnya thermal expansion yang pada akhirnya retakan mudah terjadi di batas butir. Hal ini sesuai dengan gambar struktur mikro yang menunjukkan bahwa patahan yang terjadi adalah intergranular crack.

2. Tipe II- Proses embrittlement terjadi relatif lebih cepat. Membutuhkan tegangan eksternal untuk memfasilitasi inisiasi retak berlanjut. Retak yang cenderung tegak lurus terhadap beban tarik. 


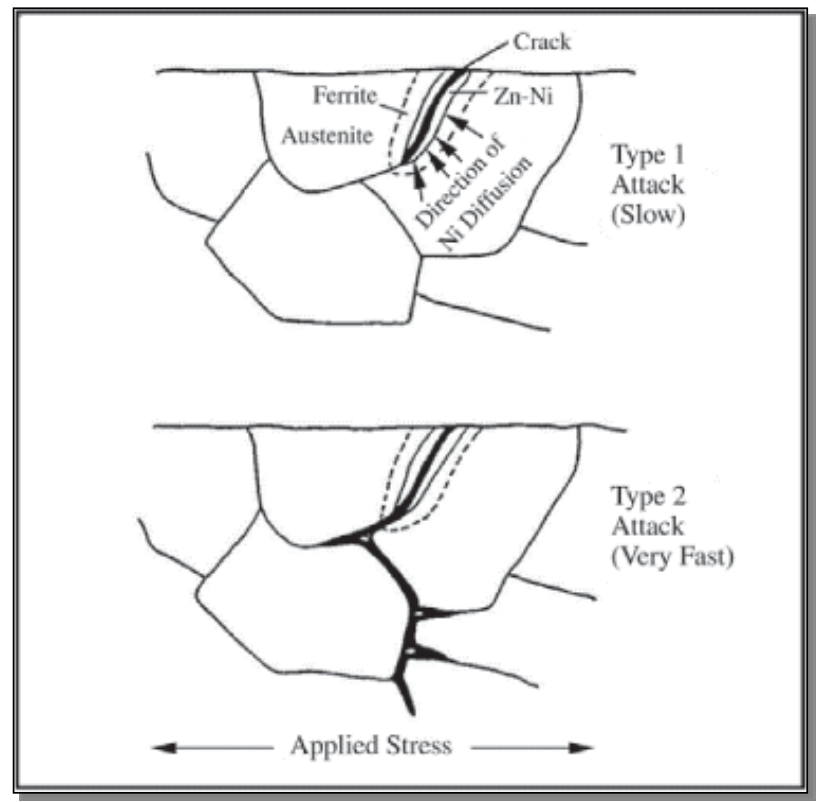

Gambar 14. Skema Mekanisme Penetrasi 2 Tipe Liquid Metal Embritllement (LME) oleh Seng pada Baja Tahan Karat Austenit [6]

Berdasarkan pemeriksaan metalografi menunjukkan bahwa retakan tegak lurus terhadap beban tarik (berasal dari internal working) dan tembus. Tipikal ini sangat sesuai dengan tipe II bahwa temperatur telah mencapai lebih dari $750^{\circ} \mathrm{C}$. Penetrasi seng yang telah sampai ke ujung permukaan retak dari arah dalam tube.

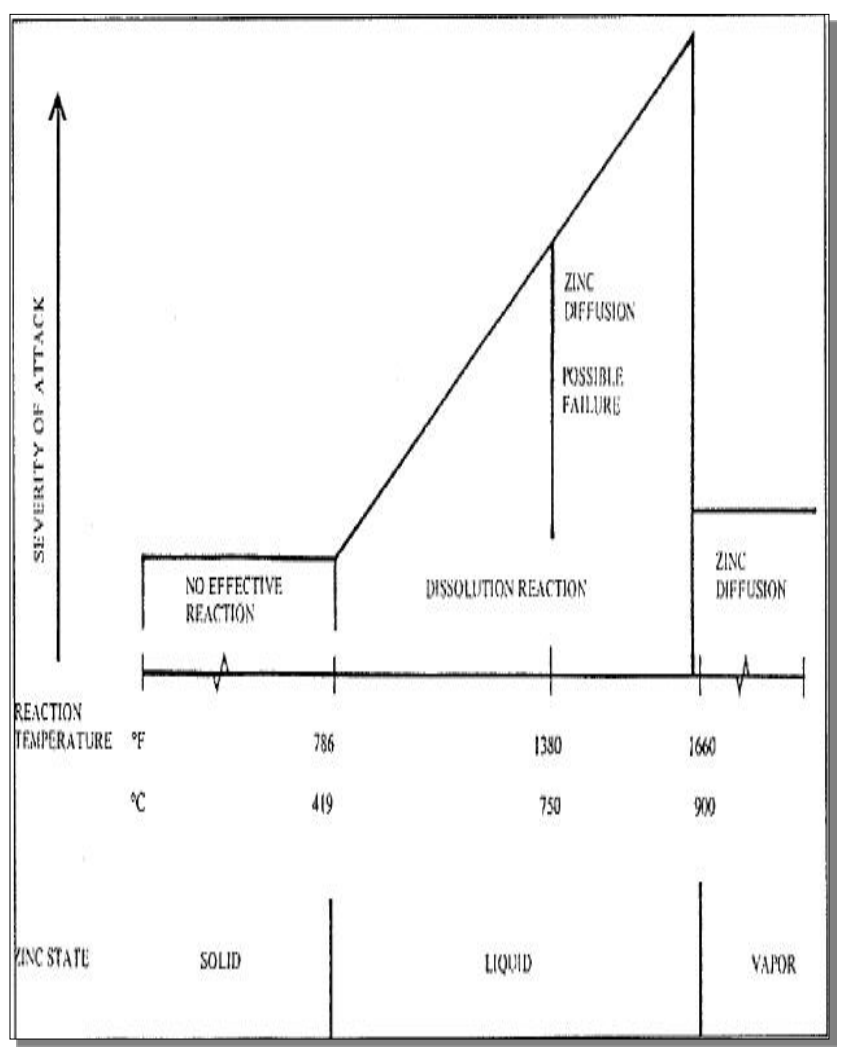

Gambar 15. Kurva Reaksi Seng dan Baja Tahan Karat Austenit Berdasarkan Temperatur [14] 
Sistem diagram fasa biner nikel-seng seperti yang ditunjukkan pada Gambar 16 memperlihatkan beberapa kemungkinan fasa yang terbentuk berdasarkan temperaturnya, yaitu: logam cair seng, fasa intermetal nikel-seng, dan larutan padat. Diagram fasa ini menjelaskan kemungkinan terbentuknya beberapa fasa intermetal nikel-seng di atas temperatur cair seng. Terbentuknya paduan antar logam nikel-seng menunjukkan terjadinya pengurangan kandungan nikel pada baja tahan karat austenitik. Penurunan kandungan nikel sebagai pembentuk fasa austenitik akan mengakibatkan terjadinya perubahan fasa menjadi feritik. Sedangkan kedua fasa tersebut memiliki ukuran volum yang berbeda, sehingga menyebabkan menjadi penyebab terjadinya penggetasan di batas butir.

Kerapuhan yang terjadi dan ditemukannya kandungan seng pada ujung retakan bagian dalam tube 316 mempertegas bahwa telah terjadi kenaikan temperatur yang signifikan sehingga masuk pada kerusakan tipe II [6].

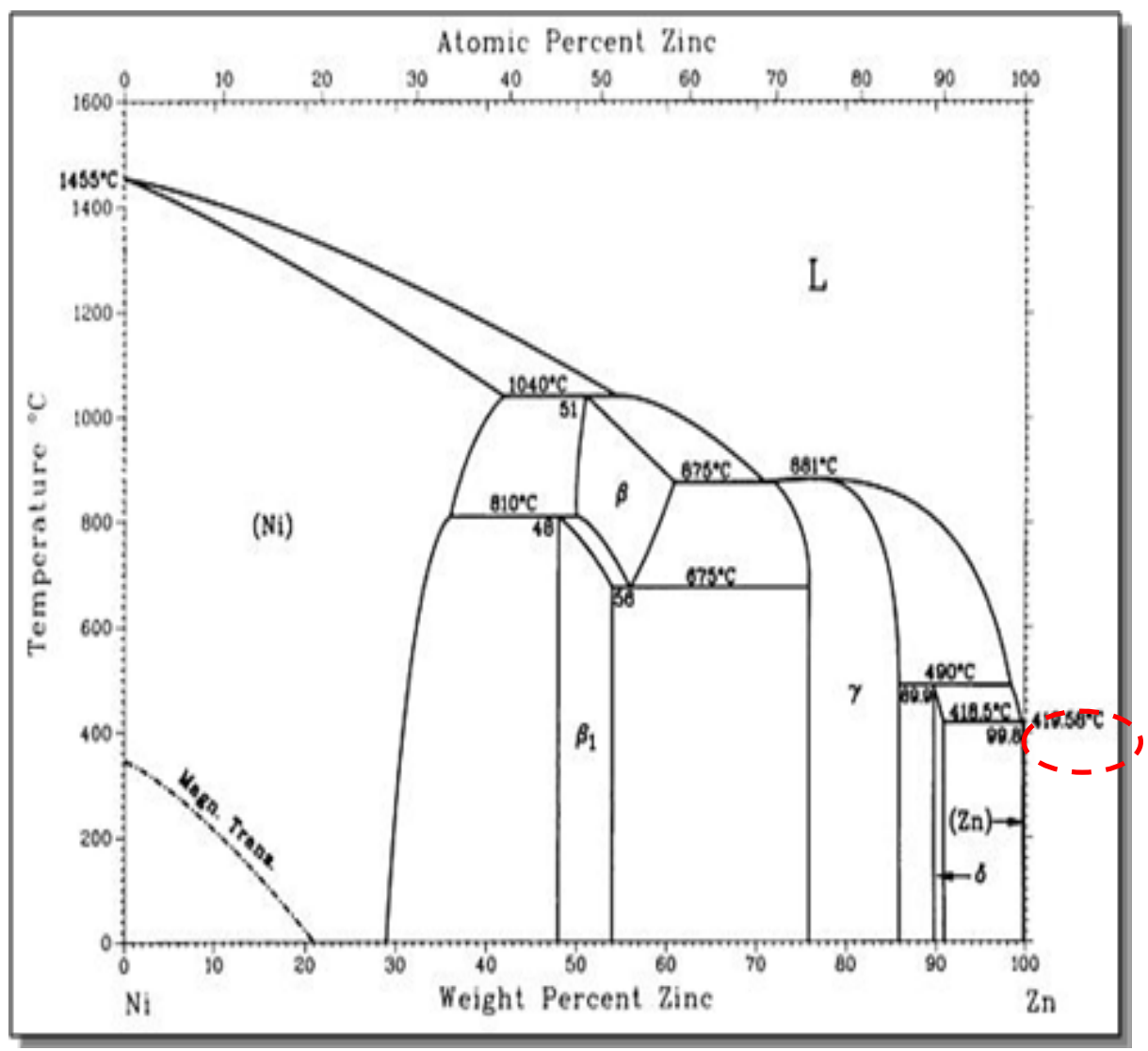

Gambar16. Diagram Fasa Biner Ni-Zn [15]

Sebagai gambaran kerapuhan yang terjadi berupa penurunan sifat keuletan dan ketangguhan baja tahan karat austenit 316 karena kontak langsung dengan seng cair. Terbentuknya senyawa intermetalik Ni-Zn pada batas butir akan mengakibatkan terjadinya fenomena nickel depletion pada batas butir. Hal ini akan mengakibatkan perubahan fasa austenit menjadi ferit terutama disekitar batas butir.
Penjelasan di atas memberikan indikasi kronologis kerusakan pada capillarytube 316, yaitu: 1. retak tranversal dari luar tube menyerang secara paralel dan bersamaan waktunya oleh fenomena LME (Liquid Metal Embrittlement) seng, 2. bocor dan perambatan retak transversal sampai sambungan las, 3. retak longitudinal pada sambungan las merambat secara bersamaan, 4 . fluida sumuran masuk ke dalam tube 316, 5. percepatan penyumbatan oleh deposit. 


\section{KESIMPULAN}

Berdasarkan serangkaian pemeriksaan dan pengujian yang telah dilakukan, diperoleh kronologi dan penyebab kerusakan sebagai berikut:

1. Retak terjadi pada tube 316 SS pada Capillary String set yang tidak terlindungi (dibungkus)/kontak langsung dengan galvanized steel.

2. Kerak yang terbentuk sebagai isolasi panas, cara pemasangan, dan adanya internal working merupakan kombinasi temperatur kontak meningkat.

3. Retak berbentuk tranversal terjadi di dareah kontak langsung antara tube 316 SS dan galvanized steel, sedangkan retak berbentuk longitudinal terjadi di daerah sambungan las.

4. Pengamatan struktur mikro menunjukkan bahwa retak intergranular cenderung tegak lurus menuju pusat diameter tube.

5. Berdasarkan hasil SEM/ EDS pada ujung retakan, baik tranversal maupun longitudinal:

- ditemukan unsur seng.

- tidak ditemukan krom (krom oksida) sebagai pelindung baja tahan karat austenit.

6. Hasil pengujian komposisi kimia pada tube yang tidak rusak dan rusak sesuai dengan ASTM A 312.

\section{Saran}

1. Hindari kontak langsung seng (galvanized steel) dengan capillary tube yang berbahan baja tahan karat austenit 316.

2. Berikan lapisan pelindung terhadap capillary tube sehingga terhindar dari kontak langsung dengan seng. Misalnya timbal, $\mathrm{Pb}$.

3. Kurangi faktor-faktor yang mempengaruhi peningkatan temperatur kontak di bawah temperatur titik cair seng.

\section{UCAPAN TERIMA KASIH}

Penulis mengucapkan terima kasih kepada Bapak Eko Budi Prakoso dan Bapak Subiyanto atas kerjasama dan kesempatan yang diberikan dalam penyusunan tulisan ini.

\section{DAFTAR PUSTAKA}

[1] Robert Heidersbach, 2010, Metallurgy and Corrosion Control in Oil and Gas Production, Wiley, New York, pp. 225.
[2] ASM International Hand Book Committee, Electronics File, 2002, "Failure Analysis and Prevention", Vol. 11, ASM International, USA, pp. 1831-1837.

[3] ASM International Hand Book Committee, Electronics File, 2003, "Corrosion”, Vol. 13A, ASM International, USA, pp. 338350.

[4] Mars G. Fontana, 1987, Corrosion Engineering, Edisi 3, McGraw-Hill Book Co, Singapore, pp. 441-443.

[5] API Recommended Practice 571, 2003, Damage Mechanism Affecting Fixed Equipment in Refining Industry, $1^{\text {st }} \mathrm{Ed}$. The American Petroleum Institute, USA, 207-211.

[6] Heloisa Cunha Furtado and Iain Le May, 2004,"High Temperature Degradation in Power Plants and Refineries", Material Research, Vol. 7, No. 1, 103-110.

[7] ASM, International Hand Book Committee,1998, "Material Characterization", Vol. 10, ASM International, USA, 48 -65.

[8] American Society for testing and Material, ASTM E 240-15, "Standard Practice for Macroetching Metals and Alloys".

[9] American Society for testing and Material, ASTM E 407-07, 2015, "Standard Practice for Microetching Metals and Alloys".

[10] American Society for testing and Material, ASTM A 312/A 312M-00c, "Standard Spesification for Seamless and Welded Austenitic Stainless Steel Pipes”.

[11] Roland METZ, 2012, " Steel Materials for Offshore Structures and Pipeline”, Total Indonesia, 61-63.

[12] ASM International Handbook Committee, 1975, "Metal of Microstructure", Vol. 7, $8^{\text {th }}$ Ed., ASM International, USA.

[13] R.M. Bruscato, 1992, "Liquid Metal Embrittlement of Austenitic Stainless Steel When Welded to Galvanized Steel”, AWS, $455-460$.

[14] Stainless Steel in Contact with Galvanized Steel,http://www.galvanizeit.org/images/up loads/drGalv/Stainless Steel in Contact with_Galvanized_Steel.pdf, diakses 12 Oktober 2015.

[15] ASM International Handbook Committee, 1992, “Alloy Phase Diagram”, Vol. 3, ASM International, USA. 